IZA DP No. 4235

Pay for Politicians and Candidate Selection: An Empirical Analysis

Kaisa Kotakorpi

Panu Poutvaara

June 2009 


\title{
Pay for Politicians and Candidate Selection: An Empirical Analysis
}

\author{
Kaisa Kotakorpi \\ University of Tampere \\ Panu Poutvaara \\ University of Helsinki \\ and IZA
}
Discussion Paper No. 4235
June 2009

\author{
IZA \\ P.O. Box 7240 \\ 53072 Bonn \\ Germany \\ Phone: +49-228-3894-0 \\ Fax: +49-228-3894-180 \\ E-mail: iza@iza.org
}

\begin{abstract}
Any opinions expressed here are those of the author(s) and not those of IZA. Research published in this series may include views on policy, but the institute itself takes no institutional policy positions.

The Institute for the Study of Labor (IZA) in Bonn is a local and virtual international research center and a place of communication between science, politics and business. IZA is an independent nonprofit organization supported by Deutsche Post Foundation. The center is associated with the University of Bonn and offers a stimulating research environment through its international network, workshops and conferences, data service, project support, research visits and doctoral program. IZA engages in (i) original and internationally competitive research in all fields of labor economics, (ii) development of policy concepts, and (iii) dissemination of research results and concepts to the interested public.
\end{abstract}

IZA Discussion Papers often represent preliminary work and are circulated to encourage discussion. Citation of such a paper should account for its provisional character. A revised version may be available directly from the author. 


\section{ABSTRACT \\ Pay for Politicians and Candidate Selection: An Empirical Analysis*}

In this paper, we estimate the effect of pay for politicians on who wants to be a politician. We take advantage of a considerable 35 percent salary increase of Finnish MPs in the year 2000 , intended to make the pay for parliamentarians more competitive. A differenceindifferences analysis, using candidates in municipal elections as a control group, suggests that the higher salary had the intended effect among women, whether measured by education or occupational qualifications. We also examine cross-party differences.

JEL Classification: D72, J3, J45

Keywords: $\quad$ pay for politicians, candidate selection, gender differences in politics

Corresponding author:

Panu Poutvaara

Department of Economics

P.O. Box 17 (Arkadiankatu 7)

00014 University of Helsinki

Finland

E-mail: panu.poutvaara@helsinki.fi

\footnotetext{
* We gratefully acknowledge financial support from the Finnish Cultural Foundation, without implicating the sponsor for the views expressed. Earlier versions of the paper were presented at the Annual Meeting of Finnish Economists in Jyväskylä, the EPCS conference in Jena and the IIPF in 2008, as well as HECER Workshop on Political Economy in Helsinki in 2009. We would like to thank Mikael Elinder, Bruno S. Frey, Alexander Haupt, Henrik Jordahl, Marko Terviö and other participants, as well as Jani-Petri Laamanen, Tuomas Takalo, Otto Toivanen and Jari Vainiomäki for helpful comments.
} 


\section{Introduction}

Representative democracy can be regarded as a principal-agent relationship where voters delegate political power to selected candidates. When doing this, voters face adverse selection and moral hazard problems. The adverse selection problem results from asymmetric information concerning the quality of candidates, as well as from the fact that voters can select politicians only from those citizens who run for the office. Selection into politics can be analyzed using the citizen-candidate models of representative democracy, pioneered by Osborne and Slivinski (1996) and Besley and Coate (1997). A moral hazard problem arises, as politicians need not act in the interest of their voters. Since it is difficult to provide formal incentives in politics, implicit incentives in the form of career concerns may mitigate the moral hazard problem (Holmström, 1982, and Persson and Tabellini, 2000).

A central tenet in the labor market literature is the idea that higher salaries can mitigate both adverse selection and moral hazard problems in labor markets: higher salaries attract more talented applicants and increase effort by employees, thus increasing the aggregate output per worker. An important question when planning compensation for elected officials is whether this holds also in politics.

The question of whether a higher pay results in a political class of higher abilities has recently attracted increasing interest - for theoretical analyses on the topic, see Besley (2004), Caselli and Morelli (2004), Messner and Polborn (2004), Poutvaara and Takalo (2007) and Matozzi and Merlo (2008). The theoretical models yield ambiguous predictions. For example, Besley (2004) finds that increasing the salaries of elected politicians need not result in a more qualified candidate body, due to a conflict between intrinsic and extrinsic motivations. A higher pay for politicians may actually result in a worse candidate pool, as extrinsic monetary incentives crowd out intrinsic public service motivations. Further, the presence of separate intrinsic and extrinsic motivations is not a necessary condition for the possibility that a salary increase would fail to attract better politicians. Poutvaara and Takalo (2007) present a model of costly campaigning that produces informative but noisy signals of candidates' abilities. They show that the common view that increasing the salaries of elected politicians improves their average abilities need not hold when campaigning is costly, even in the absence of any intrinsic motivations. 
We contribute to this discussion by providing an empirical analysis of the effect of politicians' salaries on the set of candidates. The salaries of Finnish MPs were increased by 35 percent in the year 2000. The main argument for this salary increase was that by increasing the salaries of elected politicians, it would be possible to attract more skillful citizens to politics. We examine whether the increase in the pay for MPs increased the average level of education of candidates in parliamentary elections. We use education as a proxy for skill, as more educated people typically work in more demanding jobs and receive higher pay. We also present some auxiliary evidence on the effect of the reform on the occupational background of candidates. We examine men and women separately.

We also examine whether there are cross-party differences in the effects of the salary reform. Fiorina (1994) finds that in the US context, a higher compensation and increasing professionalization of state legislatures has been associated with an increase in the fraction of Democrats. He concludes that as Republicans have, on average, higher earnings, they are discouraged from entering politics once this requires full-time commitment. On the other hand, the relationship can be expected to be non-monotonic. Once politicians are sufficiently well paid, also those with higher opportunity cost find a political career attractive. Inspired by this, we examine whether a higher salary is more effective in attracting more highly educated candidates from left-wing or right-wing parties at the national level.

There is little earlier empirical evidence on the effects of the pay for politicians on the selection of candidates and politicians. Groseclose and Krehbiel (1994), Hall and Van Houwelling (1995) and Diermeier et al. (2005) examine the effects of financial incentives on the related question of whether incumbents re-run for office. Gagliarducci et al. (2008) study the interplay between serving in politics and outside earnings. From the other side of the coin, Becker et al. (forthcoming) examine the effects of political competition on politicians' outside earnings, finding that politicians facing low competition have higher outside earnings. Ferraz and Finan (2009) find that a higher pay attracts better educated municipal candidates in Brazil. While they examine local politics, our focus is on candidates in national parliamentary elections, using candidates in municipal elections as a control group. 
To be able to distinguish the effect of the salary increase from other factors that may have affected the level of education and demographic characteristics of candidates, like the increase in the average level of education over time and the aging of the baby-boomers, we have collected information on the age, gender, education, occupation and electoral success of all parliamentary and municipal candidates in four parliamentary elections (1995, 1999, 2003 and 2007) and three municipal elections (1996, 2000 and 2004). Formally, the set of potential candidates in the parliamentary elections is our treatment group, and the set of potential candidates in the municipal elections serves as a control group. Having a treatment and a control group and data from several elections allows us to perform a difference-in-differences analysis to estimate what effects, if any, the salary increase appears to have had on the composition of the set of candidates in the parliamentary election, and on the composition of elected MPs.

A challenge for our analysis is that the trends in the fraction of candidates with higher education appear to have been different for candidates in parliamentary and municipal elections preceding the salary reform. These differing trends for the treatment and the control group imply that the assumptions for a simple difference-in-differences analysis appear not to be satisfied for the set of candidates taken as a whole. In the econometric analysis, we address this problem in two ways. Firstly, we analyze female and male candidates separately. As the underlying assumption of a similar trend in the treatment and control group before the salary increase is satisfied for female candidates, but not for male candidates, we focus on female candidates in our analysis. Secondly, we control for factors that may have affected the development of the educational background of electoral candidates over time.

Both descriptive analysis as well as formal econometric analysis suggests that the 35percent salary increase would have resulted in a more educated set of female candidates. We also find intriguing cross-party differences. Among the three largest parties, the fraction of female candidates with higher education increased after the salary reform in the Social Democratic Party and in the National Coalition Party (the largest center-right party), while there was a reduction in the Centre Party. The results hold whether we consider the set of all female candidates (new candidates as well as incumbents) or new candidates only. We also find some evidence that the fraction of female candidates working in senior expert 
positions (including occupations such as lawyers, doctors and teachers) increased after the salary reform.

The paper is organized as follows. In Section 2, we discuss the theoretical background for our analysis. In Section 3, we present institutional facts about the Finnish political system, and an overview of our data. Section 4 summarizes how the salary of Finnish MPs has changed over time, and presents the effects of the 2000 salary reform. Section 5 reports descriptive statistics about the development of the fraction of candidates with higher education. An econometric analysis is contained in section 6, and section 7 concludes.

\section{Theoretical background}

In an archetypal citizen-candidate model any citizen may enter electoral competition at a cost, and then all citizens elect politicians from the group of self-declared candidates. This approach is taken by Caselli and Morelli (2004) and Messner and Polborn (2004) who emphasize the payoff from winning an election and the opportunity cost of candidacy in determining the quality of politicians. Caselli and Morelli (2004) assume that candidates know in advance whether they can convince the electorate of their quality. Messner and Polborn (2004) assume that the abilities of potential candidates are known to voters, but their opportunity costs are private information.

Poutvaara and Takalo (2007) extend the citizen-candidate approach to take into account the role of political parties as the gatekeepers in modern democracies. In their model, political parties first select their candidates who then face each other in the general election. There are three key parameters: the reward for office holders, campaigning costs, and the citizens' ability level. The values of the parameters specify the choice between politics and a private career. Citizens contemplating candidacy weigh the expected payoff from winning an election against campaigning costs and income available outside politics. The citizens differ in their earning potential outside politics and in their competence in the office but, for each citizen, earning potential and competence are positively correlated. Voters would like to have competent office holders, but candidates have private information about their ability. Campaigning creates a noisy signal of the candidates' ability. The parties organize primary 
elections to screen the candidates so that the ability distribution of the candidates in the general election will be improved.

To give an overview of the individual maximization problem, let us assume that citizens differ in their personal characteristics, denoted by vector a, and skills, denoted by vector $\mathbf{b}$. Characteristics include gender, age, family situation, municipality, and various other aspects that are not directly related to labor market skills. Skills include formal education, previous job market experience, as well as various social skills. Skills are measured so that a larger value is associated with a higher wage. We denote the wage of individual $j$ by $w\left(\mathbf{a}_{\mathbf{j}}, \mathbf{b}_{\mathbf{j}}\right)$. Characteristics and skills are also related to the probability of electoral success. We denote the subjective probability that individual $j$ attaches to being elected by $p\left(\mathbf{a}_{\mathbf{j}}, \mathbf{b}_{\mathbf{j}}\right)$. Campaigning is costly, including both direct monetary costs, the opportunity cost of time spent, and psychological costs, net of any potential consumption benefit for those who may enjoy campaigning. We denote individual $j$ 's campaigning cost by $c_{j}$. The salary of elected politicians is $s$. Both $w\left(\mathbf{a}_{\mathbf{j}}, \mathbf{b}_{\mathbf{j}}\right)$ and $s$ are measured over the electoral term. Having served in politics also brings additional benefits, which include ego rents, as well as contacts that are possibly valuable in later working life. We denote such discounted benefits by $d_{j}$. It is attractive to run as political candidate if and only if

$$
p\left(\bar{a}_{j}, \bar{b}_{j}\right)\left(s+d_{j}\right)+\left(1-p\left(\bar{a}_{j}, \bar{b}_{j}\right)\right) w\left(\bar{a}_{j}, \bar{b}_{j}\right)-c_{j}>w\left(\bar{a}_{j}, \bar{b}_{j}\right) .
$$

Rearranging equation (1) we obtain:

$$
p\left(\bar{a}_{j}, \bar{b}_{j}\right)\left(s+d_{j}-w\left(\bar{a}_{j}, \bar{b}_{j}\right)\right)>c_{j} .
$$

Assume that a given component of the skill vector is positively related both to the probability of being elected, and to the wage rate. Then $p\left(\bar{a}_{j}, \bar{b}_{j}\right)$ is increasing in this component and $\left(s+d_{j}-w\left(\bar{a}_{j}, \bar{b}_{j}\right)\right)$ decreasing, implying that the size of their product may either increase or decrease, depending on which effect dominates. Independently of ego rents, a highly skillful candidate has ceteris paribus a higher opportunity cost of entering politics (due to having a higher outside wage), but also a higher probability of winning an election. It is therefore not clear whether more or less skillful candidates find politics more attractive, and thus the ability range from which candidates appear is unclear, à priori, and 
need not be continuous. As a result, we cannot say how an increase in the salary of elected politicians affects the average skills of candidates.

A further complication arises if we take into account that when politics becomes more attractive to all citizens, competition within politics tightens. To take this into account, we next modify the expression for the probability of being elected to include also the salary level in politics, so the probability is now given by $p\left(\mathbf{a}_{\mathbf{j}}, \mathbf{b}_{\mathbf{j}}, \mathbf{s}\right)$. Therefore, the updated condition for politics to be attractive is

$$
p\left(\bar{a}_{j}, \bar{b}_{j}, s\right)\left(s+d_{j}-w\left(\bar{a}_{j}, \bar{b}_{j}\right)\right)-c_{j}>0
$$

Differentiating the left-hand side with respect to $s$ gives

$$
p_{s}\left(\bar{a}_{j}, \bar{b}_{j}, s\right)\left(s+d_{j}-w\left(\bar{a}_{j}, \bar{b}_{j}\right)\right)+p\left(\bar{a}_{j}, \bar{b}_{j}, s\right) .
$$

It is reasonable to expect that $p_{s}\left(\bar{a}_{j}, \bar{b}_{j}, s\right)<0$, as an increase in the salary of elected politicians renders competition tougher. As a result, we cannot say, à priori, what is the sign of formula (4). While the left-hand side of condition (1) is increasing in s, implying that increasing the salary for elected politicians would make politics more attractive for all citizens, formula (4) is of ambiguous sign. While the direct effect of a salary increase encourages entry into politics, the indirect general equilibrium effect through an increased competition goes the other way. Poutvaara and Takalo (2007) analyze the overall effect when ability follows the uniform distribution, showing that the overall effect on the average ability of candidates may go either way. Increasing salaries attracts more able candidates when the initial salaries are low, and this may also result in lower-ability citizens leaving politics as the competition gets tougher and their electoral chances get worse. When salaries become sufficiently high, low-ability citizens again start entering politics, as the higher gain in case of winning outweighs the low probability of winning. In this case a further salary increase would reduce the average quality of the political class. 


\section{Institutional facts and data}

\subsection{Institutional facts}

The political setting for this study is Finland, which is a multi-party democracy with a proportional electoral system with a personal vote. Candidates are selected from electoral lists in an order determined by the number of personal votes they receive. Voters have to select a candidate they vote for. Unlike in some other countries with proportional representation, it is not possible to vote just for a party list without specifying a candidate. Finland has a one-chamber legislature, and the country is divided into fourteen mainland districts electing in total 199 legislators and the autonomous province of Åland electing one. Elections are held every four years. The number of MPs elected from the 14 mainland districts varied in 2003 between seven and 32.

In each parliamentary district, parties present lists of their candidates, typically in alphabetical order but sometimes with incumbents listed first, and each voter chooses one candidate on one list. The number of candidates that a party can present equals the number of representatives elected from the district, if this is 14 or more. In small districts with less than 14 seats, parties can present 14 candidates. The legislature seats of a given district are allocated based on party vote shares to the candidates in accordance with "competitive indices” as set by d'Hondt's method. In each party, the candidate with the highest number of votes receives as his or her competitive index the total number of votes obtained by his or her party, the candidate with the second highest number of votes obtains an index calculated as half of the party votes, the third candidate gets an index equal to a third of the party votes, etc. Then all candidates are ranked on the basis of their indices, and from this list, there will be elected as many candidates as there are seats in the electoral district.

Altogether eight different parties have seats in the current parliament. The five largest parties are the National Coalition Party (51 seats), Centre Party (51), Social Democratic Party (45), Left Alliance (17) and the Green League (14). Each major political party has typically several male and female candidates in each parliamentary district. In the 2007 parliamentary election, $40 \%$ of the candidates were female. They received approximately $42 \%$ of the votes and 84 of the 200 elected members of parliament were women. 
In municipal elections, seats are allocated using the same method as in parliamentary elections, with each municipality forming a district. The number of elected municipal councilors depends on municipality size, reaching a maximum of 85 in Helsinki. In municipal elections each party is allowed to present one and a half as many candidates on its list as the number of seats in the municipal council. The maximum number of candidates that each party can present in Helsinki is thus 127.

\subsection{Data}

We have obtained panel data on all electoral candidates in four parliamentary elections (1995, 1999, 2003 and 2007) and three municipal elections (1996, 2000 and 2004). We have information on the age, gender, political party, incumbency, and the number of personal votes of each candidate, as well as which candidates were elected. Furthermore, we have information on the occupation and education for most candidates.

In total, we have information on 8,109 of candidates in parliamentary elections and 122,754 of candidates in municipal elections. The descriptive statistics for various elections are given as Tables $1 \mathrm{a}$ and $1 \mathrm{~b}$.

Table 1a: Candidates in parliamentary elections

\begin{tabular}{|c|c|c|c|c|}
\hline & 1995 & 1999 & 2003 & 2007 \\
\hline \# of candidates & 2,083 & 1,993 & 2,029 & 2,004 \\
\hline \% of males & 60.9 & 63.0 & 60.2 & 60.1 \\
\hline Average age & 44.5 & 46.5 & 47.0 & 47.2 \\
\hline
\end{tabular}

Table 1b: Candidates in municipal elections

\begin{tabular}{|c|c|c|c|}
\hline & 1996 & 2000 & 2004 \\
\hline \# of candidates & 43,104 & 39,744 & 39,906 \\
\hline \% of males & 63.7 & 61.8 & 60.1 \\
\hline Average age & 45.2 & 46.1 & 46.9 \\
\hline
\end{tabular}

We observe that the fraction of male candidates stays relatively flat in parliamentary elections, with the exception of the election of 1999 in which their share of all candidates 
increases. However, the total number of all candidates dropped from 1995 to 1999 and the total number of male candidates also dropped. In municipal elections, there has been a steady decrease in the fraction of male candidates. The average age of candidates, on the other hand, has increased slightly in both parliamentary and municipal elections.

The register data has been obtained from various different sources. Data on education and occupation comes from Statistics Finland, while all other data on electoral candidates comes from the Ministry of Justice databases, administered by TietoEnator. Data on MP's salaries was provided by the secretariat of the Finnish parliament.

\section{The reform}

The salaries of Finnish parliamentarians have typically been lower than the salaries of MPs in most other Western European countries: a study by the secretariat of the Finnish parliament shows that in 1999, the real starting salaries of Finnish parliamentarians were lowest in the European Union. During the period 1986-1999, the salaries of MP's had also increased considerably more slowly than average earnings (Makkonen, 2000). Shortly after the 1999 parliamentary election, a proposal was made to increase the attractiveness of serving as an MP by increasing the salary of parliamentarians. The reform was accepted and the salary increase took effect on September 1, 2000. Therefore, the first election in which the candidates were affected by the reform was in 2003.

Figure 1 depicts the development of the starting salary of Finnish MPs. The figure shows that the salary change that took place in the year 2000 is both significant and unique over the time period that we are studying. The real starting salaries of MP's were practically flat preceding the reform. The reform increased the monthly starting salary of Finnish MPs from approximately $3000 €$ to $4600 €$. The change in the average salary of MPs was slightly lower, and the average effect of the reform has been calculated to have been approximately $35 \%{ }^{1}$

\footnotetext{
${ }^{1}$ At the beginning of the year 2000, there was also a small reduction in the amount of compensation for expenses incurred by MP's. At the same time, however, the compensation was made tax exempt, and the overall effect depends on each MP's marginal tax rate. Any negative effects that there may have been were nevertheless very small compared to the magnitude of the salary increase.
} 


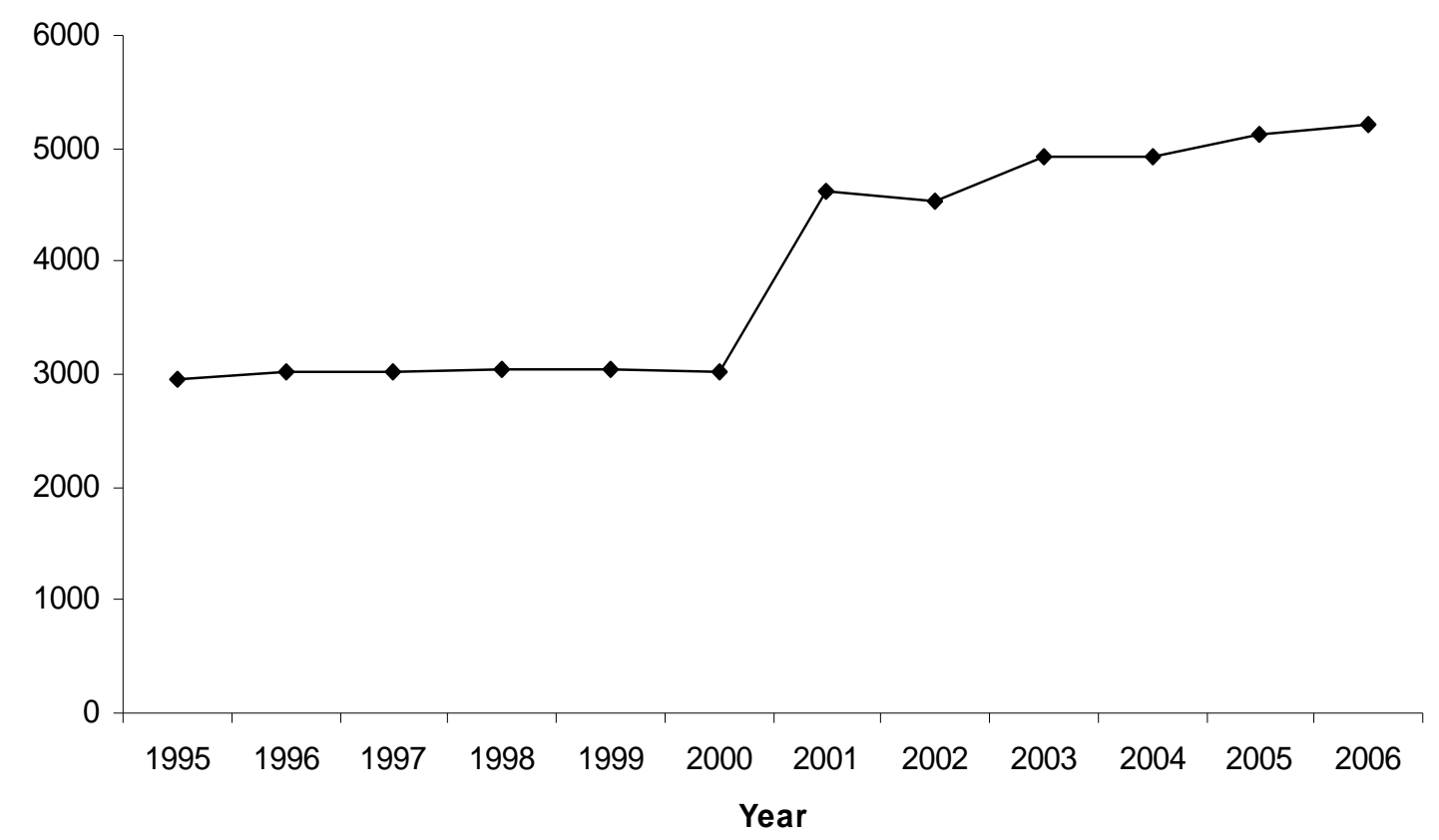

Figure 1: Starting salary of Finnish MPs (in 2002 euros)

Our econometric strategy aims at using municipal candidates as a control group for parliamentary candidates, and performing a difference-in-differences estimation to assess the effects of the reform on the educational level of parliamentary candidates. It is therefore important that the remuneration of municipal councilors should have remained constant over time. Indeed, municipal councilors do not receive a salary, but only a modest compensation for participation in meetings. There was no significant change in that compensation over the time period covered by our analysis.

\section{Educational background over time: Descriptive statistics}

\subsection{All candidates}

Figure 2 depicts the development in the fraction of parliamentary and municipal candidates with university-level education (Master's degree or more) in various elections. The fraction is calculated out of the population of all candidates, including those whose level of education is not known. We observe that the fraction of candidates with higher education is considerably higher in parliamentary elections, varying between 25 and 30 percent, while it 
is around 10 percent in municipal elections. Over the three municipal elections covered by our data, the fraction of those with university-level education increases monotonically from 9.5 percent to 12.3 percent. In the parliamentary elections, there is no monotonic trend. The fraction of candidates with university-level education declines from 27.5 percent in the 1995 election to 25.2 percent in the 1999 election, then recovering to 28.0 in the 2003 election and further increasing to 29.4 percent in the 2007 election. ${ }^{2}$

Notice that the fraction of parliamentary candidates with higher education was reduced between the two elections preceding the salary increase. After the reform, the fraction increased back to its previous level. On the other hand, the educational level of municipal candidates increased monotonically.

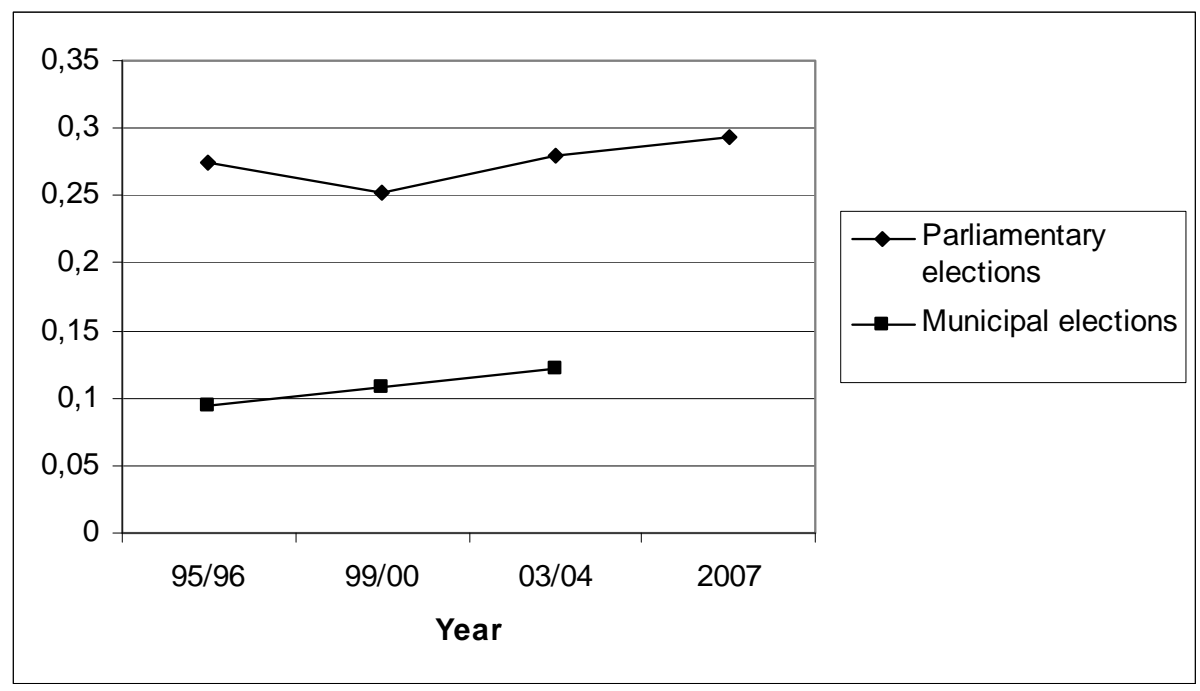

Figure 2: Proportion of candidates with higher education

It is interesting to note that the development in the educational composition of candidates in parliamentary elections seems consistent with the hypothesis that salaries have a positive effect on the educational level of candidates. As the salaries of parliamentary candidates remained flat in the period prior to the reform, it is clear that the salary development of MPs dragged behind that of other occupational groups (as on average, there was an increase in real wages over the period). That is, salaries in effect got worse when compared to wages outside politics i.e. the opportunity cost of running for office. Correspondingly, there was a

\footnotetext{
${ }^{2}$ Excluding candidates with missing observations on education does not change the qualitative picture. The only difference arises due to a larger number of missing observations in the 2007 parliamentary election.
} 
decline in the fraction of highly educated candidates in parliamentary elections prior the reform. The education level of candidates recovered after the salary increase.

The divergent trends in the level of education of parliamentary and municipal candidates before the reform pose a challenge for a formal analysis of the effect of the reform. As the difference-in-differences assumption of common underlying trends in the treatment and control groups does not seem to be fulfilled for the set of all candidates, we have also analyzed male and female candidates separately. Our econometric analysis in the next subsection shows that the difference-in-differences approach is valid for female candidates.

In figures $3 \mathrm{a}$ and $3 \mathrm{~b}$, we report the proportion of candidates with higher education among the male and female candidates.

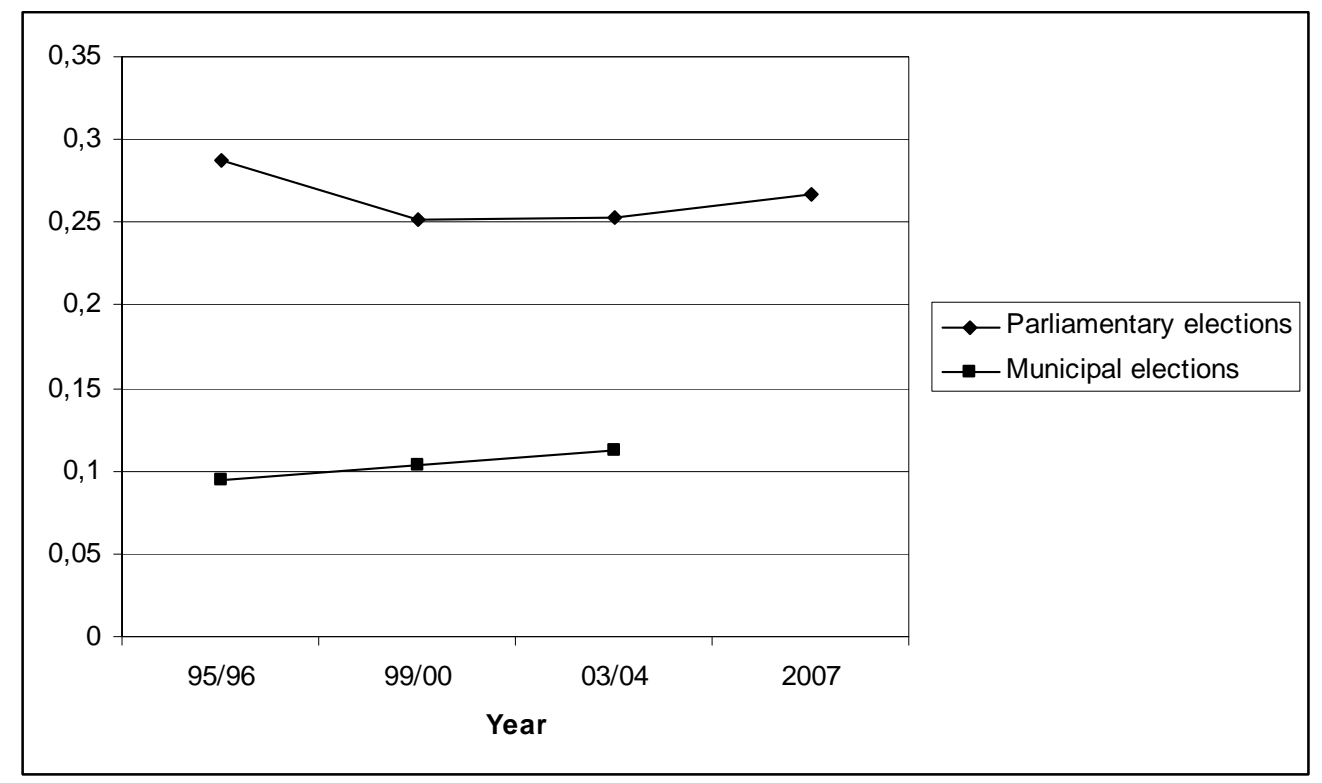

Figure 3a: Proportion of male candidates with higher education 


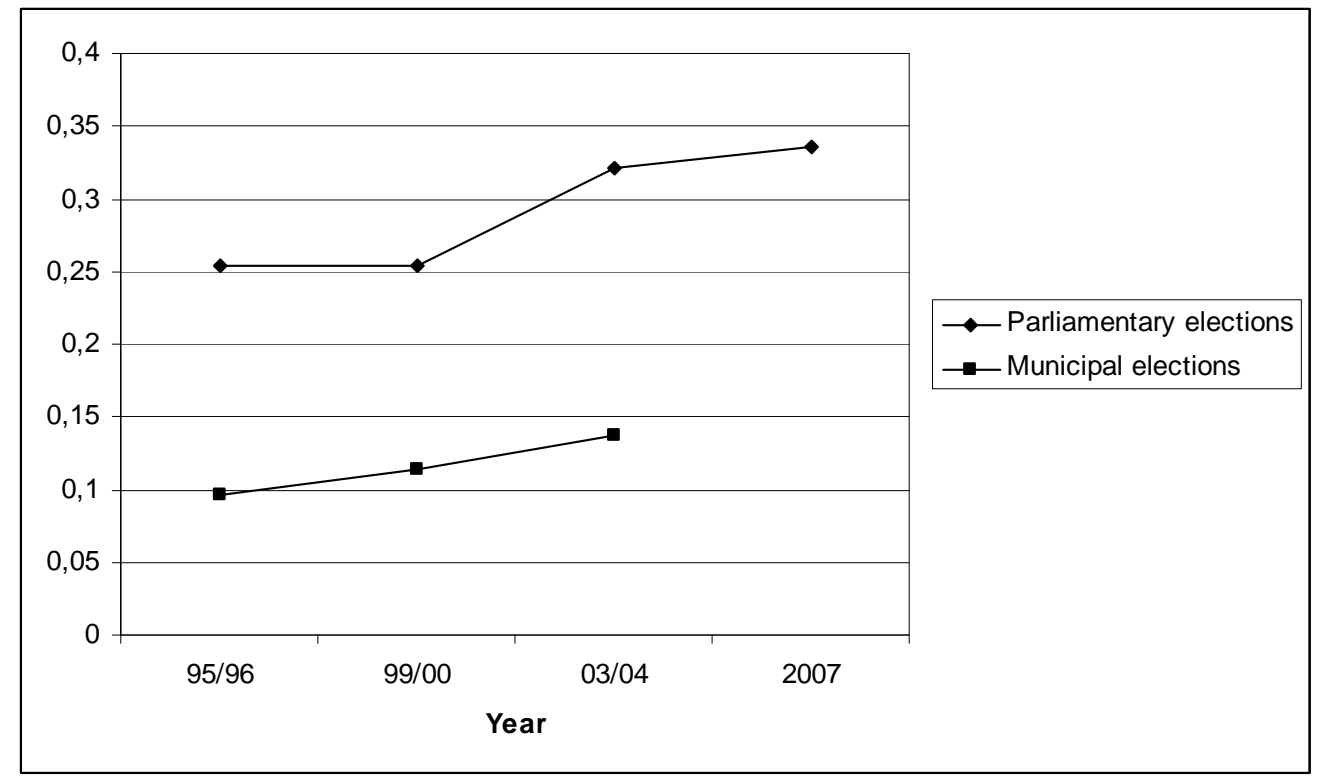

Figure 3b: Proportion of female candidates with higher education

Comparing Figures $3 \mathrm{a}$ and $3 \mathrm{~b}$ reveals that while the fraction of male parliamentary candidates has declined in subsequent elections below its 1995 level, the proportion of female candidates with higher education stayed flat in the two elections before the reform, then increasing markedly between the 1999 and 2003 elections, after the salary increase. One should highlight, however, that these descriptive statistics should not be interpreted as any claim about causality, and we perform the formal econometric analysis of the effect of the reform in the next section.

For comparison, Figure 4 shows the development in the educational background of the adult population (individuals aged 15 or over) as a whole. While low compared to the educational level of parliamentary candidates, the education level of both men and women has increased steadily over time. This gives us confidence that there should have been no changes in the educational composition of the electorate that would obfuscate the analysis. 


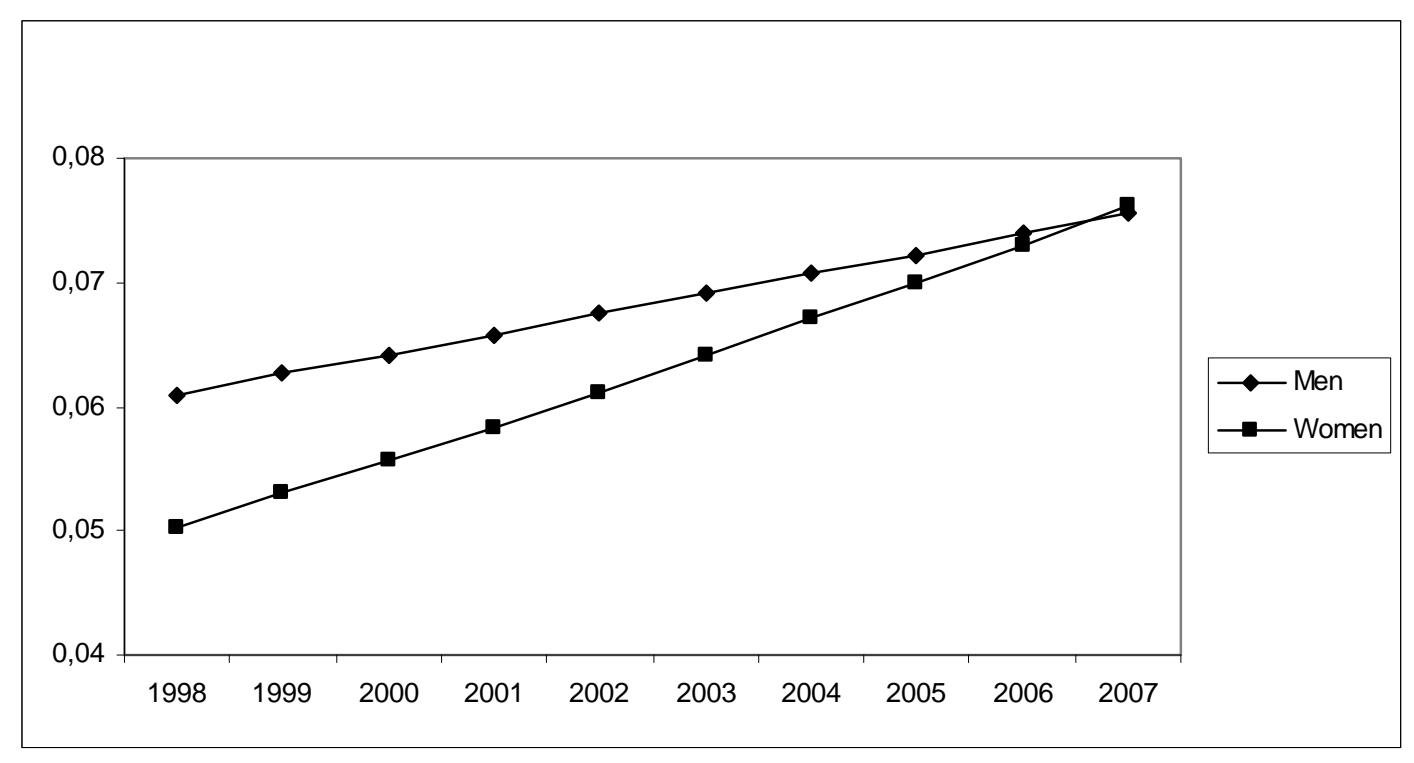

Figure 4: Proportion of adult citizens with higher education

\subsection{Cross-party differences}

As the difference-in-differences assumptions appear not to be satisfied for the pool of candidates as a whole or for male candidates taken separately, the descriptive analysis in the current subsection, as well as the formal econometric analysis below, concentrates on female candidates only. In Figures 5a-5e, we present the development in the fraction of highly educated female candidates for the five largest parties (organized from left to right) ${ }^{3}$.

After the salary increase, the fraction of highly educated female candidates increased markedly both on the left (notably in the Social Democratic Party) and on the right (the National Coalition Party), while it seems that there was no major change for the Centre Party. There was a large increase in the fraction of highly educated female candidates also in the Green League. In the Left Alliance, the fraction of university-educated candidates first increased and then dropped almost back to its pre-reform level.

\footnotetext{
${ }^{3}$ Note that the placement of the Green League on the left-right axis is ambiguous and open to interpretation.
} 

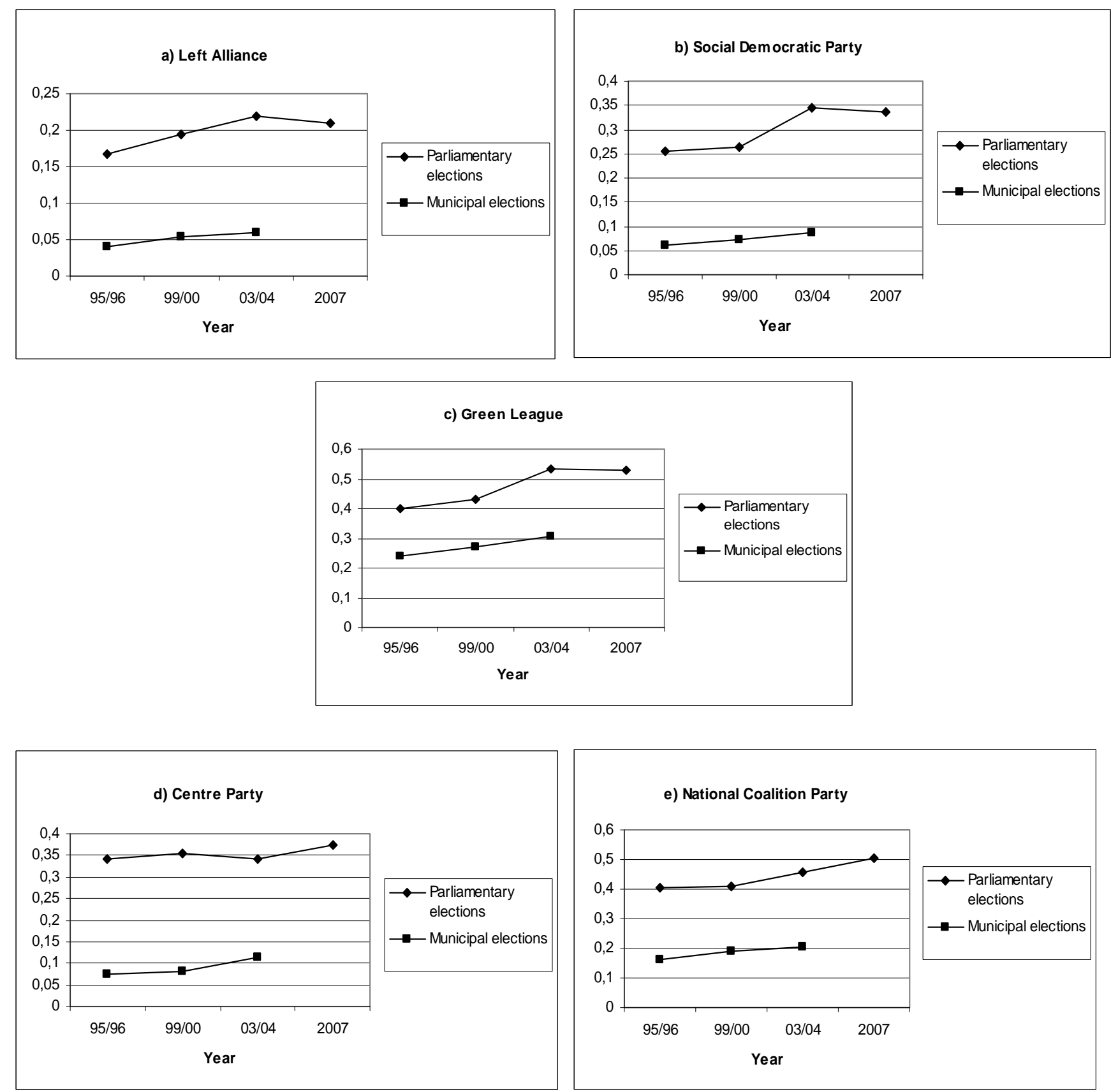

Figure 5: Proportion of female candidates with higher education in the five largest

\section{parties}




\section{Salary reform and candidate pool: An econometric analysis}

\subsection{Educational background of female candidates}

\subsubsection{All female candidates}

Our econometric strategy aims at using municipal candidates as a control group for parliamentary candidates, and performing a difference-in-differences estimation to compare how the development in the fraction of highly-educated parliamentary candidates differs from the development in the fraction of highly-educated municipal candidates. However, as is evident from Figures 2 and 3a, a simple difference-in-differences analysis of the entire candidate pool or male candidates would be problematic, as the trends in the fraction of candidates with higher education appear to differ between parliamentary and municipal elections even before the reform. Also formal econometric tests give the same result: the difference-in-differences approach cannot be used to study the effects of the salary reform for the whole candidate population, or for male candidates. Therefore, we now turn our attention to females only.

To ensure the validity of our approach, we perform a t-test to examine whether the change in the proportion of female candidates with higher education from the 1995 to the 1999 parliamentary election, was equal to the change in that proportion from the 1996 to the 2000 municipal election. The null hypothesis that these changes are equal is not rejected (the p-value is 0.60 ).

The estimation results of the effect of the salary reform for female candidates are reported in Table 2. Column a) provides a simple difference-in-differences analysis without covariates. The dependent variable is a dummy for whether the candidate has a higher education. The parliamentary election -dummy takes into account the difference in the overall education level of parliamentary and municipal candidates. The dummy for the time after the reform controls for the time trend in the level of education. The coefficient for the interaction term between these two dummies gives the difference-in-differences estimate for the effect of the salary reform on the education level of candidates in parliamentary elections. We carry out the estimation using a linear probability model (OLS). To account for the fact that some individuals appear several times in the data (as the same individuals 
run for several elections) and that there is naturally a strong correlation in the education level of a given candidate in different elections, we cluster the standard errors by candidate. Note that in all the estimations, we have dropped the data for the 2007 parliamentary elections, as we do not have a control group this set of candidates. In all of the analyses, the fraction of candidates with higher education has been calculated out of the population of all candidates, including those whose level of education is not known. Excluding candidates with missing values for education does not affect the results.

The results reported in column a) of Table 2 show that for female candidates, the effect of the reform is statistically significant at the 5-percent confidence level. The reform appears to have led to approximately a 3,5\%-point increase in the fraction of parliamentary candidates with higher education.

In order for the simple difference-in-differences analysis to provide a full picture, we would have to assume that all relevant background characteristics that may affect the level of education have changed in a similar way for candidates in parliamentary and municipal elections. In particular, the reader might worry that any changes in the educational composition of candidates may also be explained by changes in the age structure of candidates, given that younger cohorts are typically better educated, and some of the youngest candidates have not yet completed their education. Further, incumbents and new candidates may have different backgrounds. ${ }^{4}$ In column b) of Table 2 we report the results from a regression that controls for these background characteristics. Compared with the basic difference-in-differences estimate in column a), we include dummies for different age cohorts as well as an incumbency dummy.

\footnotetext{
${ }^{4}$ We are mainly interested in selection into politics and therefore on the effect of the salary reform on new candidates. We nevertheless include incumbents in the analysis, as incumbents also need to decide whether or not to re-run for office, and this decision may be affected by MP's salaries.
} 
Table 2: Salary reform and higher education of female candidates

\begin{tabular}{|c|c|c|c|}
\hline \multicolumn{4}{|c|}{ Dependent variable: Higher education dummy } \\
\hline & a) & b) & c) \\
\hline \multirow[t]{2}{*}{ Parliamentary election } & $0.14866^{* * *}$ & $0.15424 * * *$ & $0.13623^{* * *}$ \\
\hline & $(0.01229)$ & $(0.01222)$ & $(0.01209)$ \\
\hline \multirow[t]{2}{*}{ Time after reform } & $0.03205^{* * *}$ & $0.03451 * * *$ & $0.03183^{* * *}$ \\
\hline & $(0.00257)$ & $(0.00260)$ & $(0.00257)$ \\
\hline Time after reform * & $0.03463^{* *}$ & $0.03662^{* *}$ & $0.04013^{* *}$ \\
\hline Parliamentary election & $(0.01720)$ & $(0.01690)$ & $(.01664)$ \\
\hline \multirow[t]{2}{*}{ Age: 30-39 } & & $0.10357^{* * *}$ & $0.10581^{* * *}$ \\
\hline & & $(0.00509)$ & $(0.00505)$ \\
\hline \multirow[t]{2}{*}{$40-49$} & & $0.07073 * * *$ & $0.07842 * * *$ \\
\hline & & $(0.00475)$ & $(0.00477)$ \\
\hline \multirow[t]{2}{*}{$50-59$} & & $0.05488 * * *$ & $0.06446 * * *$ \\
\hline & & $(0.00507)$ & $(0.00511)$ \\
\hline \multirow[t]{2}{*}{$60+$} & & $0.02080 * * *$ & $0.03146 * * *$ \\
\hline & & $(0.00618)$ & $(0.00621)$ \\
\hline \multirow[t]{2}{*}{ Incumbent } & & $0.05986^{* * *}$ & $0.06341^{* * *}$ \\
\hline & & $(0.00579)$ & $(0.00567)$ \\
\hline \multirow[t]{2}{*}{ Party: Social Democratic Party } & & & $-0.04448 * * *$ \\
\hline & & & $(0.00646)$ \\
\hline \multirow[t]{2}{*}{ Centre Party } & & & $-0.02854 * * *$ \\
\hline & & & $(0.00621)$ \\
\hline \multirow[t]{2}{*}{ National Coalition Party } & & & $0.07235^{* * *}$ \\
\hline & & & $(0.00761)$ \\
\hline \multirow[t]{2}{*}{ Green League } & & & $0.16028 * * *$ \\
\hline & & & $(0.01294)$ \\
\hline \multirow[t]{2}{*}{ Left Alliance } & & & $-0.06390 * * *$ \\
\hline & & & $(0.00738)$ \\
\hline \multirow[t]{2}{*}{ Constant } & $0.10521^{* * *}$ & $0.03367 * * *$ & $0.02943^{* * *}$ \\
\hline & $(0.00212)$ & $(0.00323)$ & $(0.00574)$ \\
\hline Number of observations & 49117 & 49117 & 49117 \\
\hline Adjusted R-squared & 0.0133 & 0.0277 & 0.0599 \\
\hline
\end{tabular}

The results in column b) of Table 2 confirm the results of the simple difference-indifferences analysis. If anything, the effect of the reform is now slightly stronger than in the 
analysis without control variables. Our results therefore indicate that the reform has led to an increase in the fraction of female parliamentary candidates with higher education.

We have run robustness checks where we have included controls for the candidate's party affiliation, in order to account for the possibility that candidates in different parties may have different backgrounds. In particular, candidates of the Green League and the National Coalition Party appear on average to be more highly educated, and candidates of the left wing parties (Social Democratic Party, Left Alliance) less highly educated than candidates of other parties. This might affect our results if the numbers of candidates from different parties vary between elections. Our results are robust to controlling for the effect of party affiliation: In column c) of table 2 we include dummies for the 5 largest parties, and this makes the effect of the reform larger and more significant (the parameter estimate increases to slightly over $4 \%$ and the associated p-value drops from 0,030 to 0,016 ). When we add the controls for individual parties, the result regarding the effect of the reform is also robust (at the 10\%-level) to leaving out candidates of any one of the five largest parties, indicating that our results are not caused for example by changes in any one party.

As expected, the effect that we have estimated comes mainly from new candidates (rather than more highly educated incumbents deciding to re-run for office). If we do the estimation separately for new candidates, the results are very similar to those reported in table 2: the estimated effect of the reform is 0.03924 and the p-value is 0.031 . On the other hand, doing the estimation separately for incumbents yields a smaller and insignificant effect: the point estimate is 0.0296 and the p-value is 0.613 . Note however that the small number of incumbent candidates (169, out of which 65 were female in the 2003 elections) in itself makes the detection of any statistically significant effects for incumbents unlikely.

As a further robustness check, we have also estimated the effect of a pseudo reform, assumed to take place one electoral period earlier, along the approach suggested by Bertrand et al. (2004). The effect of the pseudo reform on the fraction of female candidates with higher education is not statistically significant: the point estimate for the effect of the pseudo reform is 0.01041 and the p-value is 0.529 . 


\subsubsection{Female candidates of the five main parties}

As established in Figures 5a-e and in column c of Table 2, there are significant cross-party differences in the educational qualifications of candidates. Therefore, we have examined the effects of the salary reform separately for each of the five largest parties. The null hypothesis of the parallel trend assumption before the salary increase is not rejected for any party. The results of a difference-in-differences analysis with covariates are presented in Table 3.

Even though the effect of the reform is not significant at the level of individual parties, the point estimates reported in Table 3 indicate that there are interesting differences in the effect of the reform between parties. In the Social Democratic Party and the Green League the estimated effect of the reform on the fraction of female candidates with higher education is over $6 \%$-points and in the National Coalition Party and the Left Alliance it is over $3 \%$-points, i.e. close to the average effect. In the Centre Party, on the other hand, the reform appears to have led to a reduction in the fraction of female candidates with higher education. There appear to be cross-party differences in the other coefficients as well: for instance, the difference between the average level of education of parliamentary and municipal candidates is highest in the Centre Party and lowest in the Left Alliance.

If we do the analysis for new candidates only, the results are similar to those reported in Table 3. The main differences are that the estimated effect for new candidates in the National Coalition Party is larger than the effect reported in Table 3 (approximately 6,5 \%points), and for new candidates in the Left Alliance it is somewhat smaller (approximately 1,5 \%-points). Again, the party-level effects are not statistically significant, even though the average effect (for all parties or for the five largest parties taken together) is. 
Table 3: Salary reform and higher education of female candidates in the five largest parties

\begin{tabular}{|c|c|c|c|c|c|}
\hline \multicolumn{6}{|c|}{ Dependent variable: Higher education dummy } \\
\hline & $\begin{array}{l}\text { a) Left } \\
\text { Alliance }\end{array}$ & $\begin{array}{l}\text { b) Social } \\
\text { Democratic } \\
\text { Party }\end{array}$ & $\begin{array}{l}\text { c) Green } \\
\text { League }\end{array}$ & $\begin{array}{l}\text { d) Centre } \\
\text { Party }\end{array}$ & $\begin{array}{l}\text { e) National } \\
\text { Coalition } \\
\text { Party }\end{array}$ \\
\hline \multirow[t]{2}{*}{ Parliamentary election } & $0.13562 * * *$ & $0.19295^{* * *}$ & $0.16672 * * *$ & $0.27396^{* * *}$ & $0.22704^{* * *}$ \\
\hline & $(0.03388)$ & $(0.03502)$ & $(0.03466)$ & $(0.04319)$ & $(0.03873)$ \\
\hline \multirow[t]{2}{*}{ Time after reform } & $0.01629 * * *$ & $0.02193^{* * *}$ & $0.05748^{* * *}$ & $0.03529 * * *$ & $0.02829 * * *$ \\
\hline & $(0.00504)$ & $(0.00434)$ & $(0.01516)$ & $(0.00464)$ & $(0.00719)$ \\
\hline Time after reform * & 0.03069 & 0.06364 & 0.06619 & -0.04390 & 0.03552 \\
\hline Parliamentary election & $(0.03875)$ & $(0.04489)$ & $(0.05071)$ & $(0.05353)$ & $(0.05305)$ \\
\hline \multirow[t]{2}{*}{ Age: $30-39$} & $0.05408^{* * *}$ & $0.05978^{* * *}$ & $0.21716^{* * *}$ & $0.07730^{* * *}$ & $0.16111^{* * *}$ \\
\hline & $(0.01313)$ & $(0.00930)$ & $(0.02447)$ & $(0.00777)$ & $(0.01390)$ \\
\hline \multirow[t]{2}{*}{$40-49$} & $0.05612^{* * *}$ & $0.04143^{* * *}$ & $0.19536^{* * *}$ & $0.05334 * * *$ & $0.11045^{* * *}$ \\
\hline & $(0.01167)$ & $(0.00907)$ & $(0.02546)$ & $(0.00765)$ & $(0.01296)$ \\
\hline \multirow[t]{2}{*}{$50-59$} & $0.04149 * * *$ & $0.03147^{* * *}$ & $0.20065^{* * *}$ & $0.04709 * * *$ & $0.08247^{* * *}$ \\
\hline & $(0.01161)$ & $(0.00956)$ & $(0.03118)$ & $(0.00867)$ & $(0.01364)$ \\
\hline \multirow[t]{2}{*}{$60+$} & 0.00439 & 0.00444 & $0.09439 * *$ & $0.02491^{* *}$ & $0.06205^{* * *}$ \\
\hline & $(0.00973)$ & $(0.01075)$ & $(0.04682)$ & $(0.01133)$ & $(0.01786)$ \\
\hline \multirow[t]{2}{*}{ Incumbent } & $0.04857 * * *$ & $0.05876^{* * *}$ & $0.18411^{* * *}$ & $0.04113^{* * *}$ & $0.07982 * * *$ \\
\hline & $(0.01558)$ & $(0.01006)$ & $(0.03272)$ & $(0.00954)$ & $(0.01511)$ \\
\hline \multirow[t]{2}{*}{ Constant } & -0.00136 & $0.02011^{* * *}$ & $0.06422^{* * *}$ & $0.02140^{* * *}$ & $0.06849 * * *$ \\
\hline & $(0.00740)$ & $(0.00614)$ & $(0.01583)$ & $(0.00511)$ & $(0.00912)$ \\
\hline Number of observations & 4906 & 10592 & 2860 & 13454 & 9161 \\
\hline Adjusted R-squared & 0.0340 & 0.0320 & 0.0739 & 0.0266 & 0.0333 \\
\hline
\end{tabular}

\subsection{Occupational background of female candidates}

Finally, we report some evidence on the development of the occupational background of female candidates. ${ }^{5}$ The occupational classification of Statistics Finland has 9 main groups: 1) managers; 2) senior experts; 3) experts; 4) office and customer service workers; 5) workers in services, sales and nursing; 6) farmers; 7) workers in construction and production; 8) workers in industry and transport; 9) other. Out of these groups, the first two

\footnotetext{
${ }^{5}$ Again, the difference in differences assumptions appear to be satisfied for women but not for men (or the candidate pool taken as a whole), and we therefore continue to analyze female candidates only.
} 
require the highest qualifications and are therefore the ones that are most interesting from the point of view of our study. Category 1 includes managers and top officials in both the private and the public sector. Category 2 includes for example doctors, lawyers and teachers. ${ }^{6}$

In Table 4, we present a difference-in-differences analysis of the effect of the reform on the fraction of managers and senior experts among female candidates in parliamentary elections. We include the same controls as in column c of Table 2. In the case of managers, the estimated effect of the reform is very small and not statistically significant. In the case of senior experts, on the other hand, the effect of the reform is slightly over $3 \%$-points and it is statistically significant at the $10 \%$ level. Again, we have checked that the effect of pseudo-reform, assumed to take place one electoral period earlier, is not significant. This provides some further evidence that the salary increase has resulted in an increase in the average level of qualifications of female candidates in parliamentary elections.

However, the effect on the occupational qualifications of female parliamentary candidates does not appear to be as robust as the effect on the average level of education: the effect of the reform is only significant at the $10 \%$-level and if we do the analysis for new candidates only, the effect of the reform is no more statistically significant. Again, there appear to be cross-party differences in the effect of the reform - see the figures in the appendix. The reform loses its significance if candidates of the Social Democratic Party, the National Coalition, or the Left Alliance are left out of the analysis.

\footnotetext{
${ }^{6}$ In contrast, category 3 includes occupations in all sectors that require some special type of expertise (below the managerial or senior expert level) - examples include real estate agents, policemen and nurses.
} 
Table 4: Salary reform and occupational background of female candidates

\begin{tabular}{|c|c|c|}
\hline & $\begin{array}{l}\text { a) Dep. var: } \\
\text { manager- } \\
\text { dummy }\end{array}$ & $\begin{array}{l}\text { b) Dep. var: } \\
\text { senior expert - } \\
\text { dummy }\end{array}$ \\
\hline Parliamentary election & $\begin{array}{l}0.10420 * * * \\
(0.00972)\end{array}$ & $\begin{array}{l}0.08432 * * * \\
(0.01170)\end{array}$ \\
\hline Time after reform & $\begin{array}{l}0.00026 \\
(0.00158)\end{array}$ & $\begin{array}{l}0.02856^{* * *} \\
(0.00331)\end{array}$ \\
\hline Time after reform * & -0.00754 & $0.03242 *$ \\
\hline Parliamentary election & $(0.01208)$ & $(0.01839)$ \\
\hline Age: 30-39 & $\begin{array}{l}0.02107 * * * \\
(0.00269)\end{array}$ & $\begin{array}{l}0.09809 * * * \\
(0.00601)\end{array}$ \\
\hline $40-49$ & $\begin{array}{l}0.03073 * * * \\
(0.00269)\end{array}$ & $\begin{array}{l}0.10592 * * * \\
(0.00590)\end{array}$ \\
\hline $50-59$ & $\begin{array}{l}0.03388 * * * \\
(0.00299)\end{array}$ & $\begin{array}{l}0.08985 * * * \\
(0.00622)\end{array}$ \\
\hline $60+$ & $\begin{array}{l}0.00170 \\
(0.00276)\end{array}$ & $\begin{array}{l}-0.04015^{* * *} \\
(0.00612)\end{array}$ \\
\hline Incumbent & $\begin{array}{l}0.04680 * * * \\
(0.00410)\end{array}$ & $\begin{array}{l}0.06984 * * * \\
(0.00596)\end{array}$ \\
\hline Party: Social Democratic Party & $\begin{array}{l}0.01371^{* * *} \\
(0.00380)\end{array}$ & $\begin{array}{l}-0.04775^{* * *} \\
(0.00687)\end{array}$ \\
\hline Centre Party & $\begin{array}{l}0.00604 * \\
(0.00317)\end{array}$ & $\begin{array}{l}-0.02382 * * * \\
(0.00666)\end{array}$ \\
\hline National Coalition Party & $\begin{array}{l}0.38763 * * * \\
(0.00415)\end{array}$ & $\begin{array}{l}0.09002 * * * \\
(0.00783)\end{array}$ \\
\hline Green League & $\begin{array}{l}0.01296 * * \\
(0.00581)\end{array}$ & $\begin{array}{l}0.15965 * * * \\
(0.01230)\end{array}$ \\
\hline Left Alliance & $\begin{array}{l}-0.00799 * * \\
(0.00376)\end{array}$ & $\begin{array}{l}-0.07514^{* * *} \\
(0.00818)\end{array}$ \\
\hline Constant & $\begin{array}{l}-0.00868 * * \\
(0.00292)\end{array}$ & $\begin{array}{l}0.08368 * * * \\
(0.00654)\end{array}$ \\
\hline Number of observations & 49117 & 49117 \\
\hline Adjusted R-squared & 0.0302 & 0.0527 \\
\hline
\end{tabular}




\section{Conclusion}

In this paper, we have tested whether paying higher salaries for parliamentarians has resulted in a more highly educated set of candidates. Our results suggest that the salary increase for parliamentarians has attracted more educated female candidates. The estimated effects differ between the five main parties. However, such differences do not correspond to the divide between the political left and the political right. The estimated effect is positive for the largest party on the right and on the left, while being negative but small for the largest centrist party. When studying occupational groups, we find that the salary increase resulted in a somewhat higher fraction of highly-skilled workers among female parliamentary candidates.

An important assumption in our analysis is that the salary reform of parliamentarians should have no effect on the incentives of becoming a candidate in municipal elections. The reader might worry whether higher salaries for parliamentarians may also amount to higher prospective earnings for current municipal councilors, if being a municipal councilor serves as a stepping stone for later becoming an $\mathrm{MP}^{7}$. This would imply that there is a positive treatment also for municipal candidates (though probably small compared to the treatment for parliamentary candidates). The possible effect of this consideration is slightly mitigated in our context by the fact that municipal elections take place in the year after parliamentary elections. Further, it is important to note that if such a mechanism is indeed operational, this would amount to a negative bias in our estimates of the effect of the reform on parliamentary candidates. The effect that we find can therefore be considered as the lower bound for the actual effect of the salary reform.

\footnotetext{
${ }^{7}$ Unfortunately, we do not have data on how many parliamentary candidates have previously served as municipal councilors. As an incomplete proxy, our data for the 2007 parliamentary elections shows that of the candidates in that election in the Helsinki constituency, 5.2\% were current municipal councilors. This data is not available for the other elections or other constituencies.
} 


\section{Appendix}

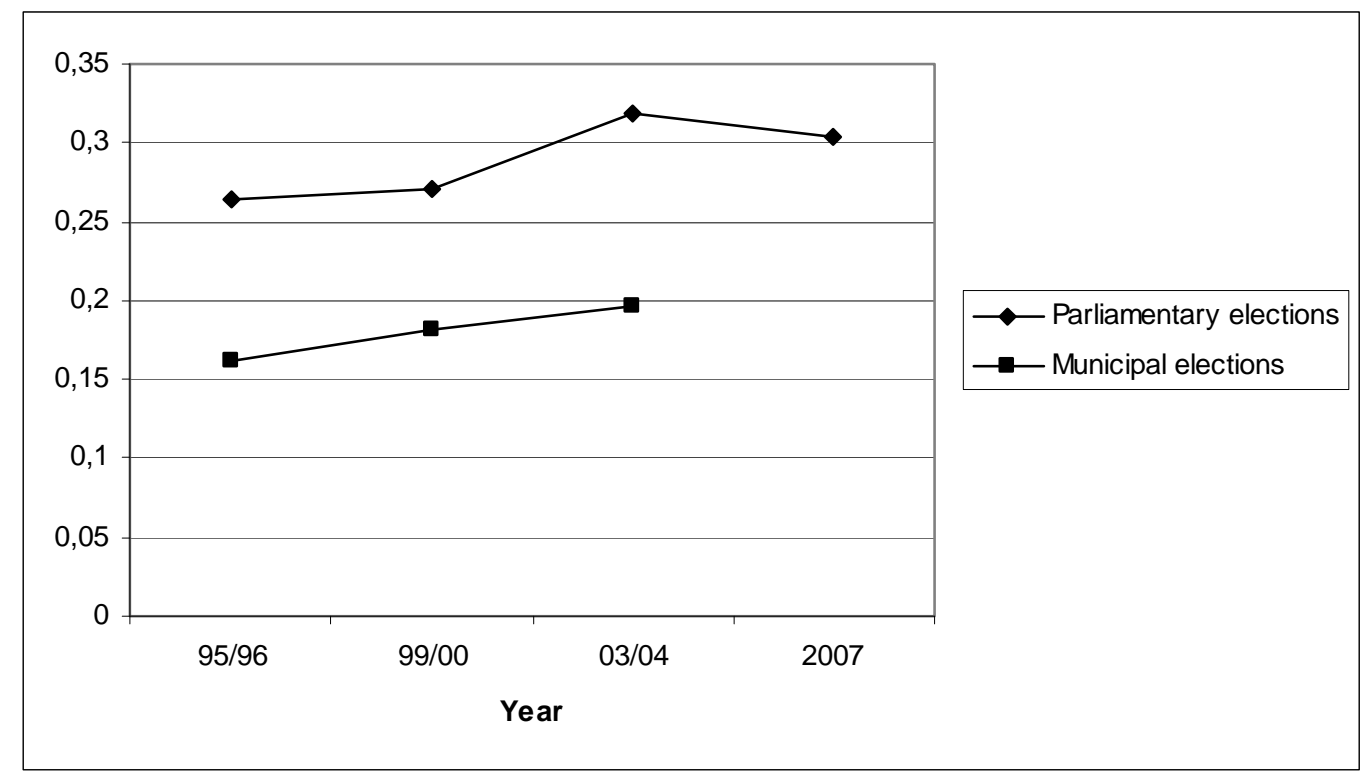

Figure A1. Fraction of senior experts among female candidates 

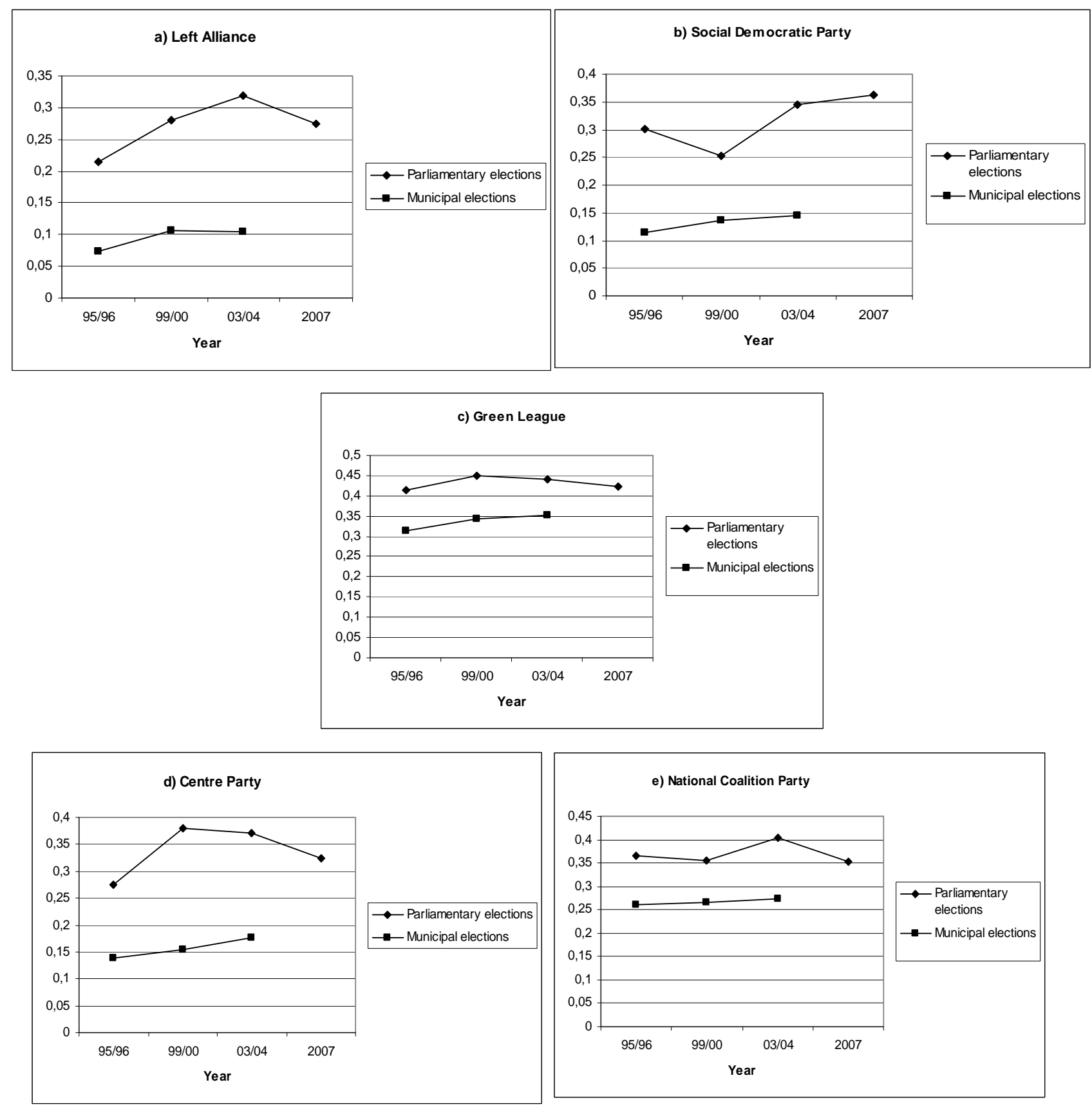

Figure A2. Fraction of senior experts among female candidates: five largest parties

\section{References}

Becker, J., Peichl, A., and Rincke, J. (forthcoming) “Politicians' Outside Earnings and Political Competition.” Public Choice.

Bertrand, M., Duflo, E. and Mullainathan, S. (2004). "How Much Should We Trust Differences-in-Differences Estimates?” Quarterly Journal of Economics 119, 249-275. 
Besley, T. (2004). "Paying Politicians: Theory and Evidence.” Journal of the European Economic Association 2, 193-215.

Besley, T. and Coate, S. (1997). “An Economic Model of Representative Democracy.” Quarterly Journal of Economics 112, 85-114.

Caselli, F. and Morelli, M. (2004). “Bad Politicians.” Journal of Public Economics 88, 759782.

Diermeier, D., Keane, M. and Merlo, A. (2005). “A Political Economy Model of Congressional Careers.” American Economic Review 95, 347-373.

Ferraz, C. and Finan, F. (2009). "Motivating Politicians: The Impact of Monetary Incentives on Quality and Performance.” NBER WP 14906.

Fiorina, M. P. (1994). "Divided Government in the American States: A Byproduct of Legislative Professionalism?” American Political Science Review 88, 304-316.

Gagliarducci, S., Nannicini, T. and Naticchioni, P. (2008). "Outside Income and Moral Hazard: The Elusive Quest for Good Politicians.” IZA DP 3295.

Groseclose, T. and Krehbiel, K. (1994). "Golden Parachutes, Rubber Checks, and Strategic Retirements from the 102nd House.” American Journal of Political Science 38, 75-99.

Hall, R. L. and Van Houwelling, R. P. (1995). “Avarice and Ambition in Congress: Representatives' Decisions to Run or Retire from the US House." American Political Science Review 89, 121-136.

Holmström, B. (1982). "Managerial Incentive Problem - A Dynamic Perspective," in Essays in Economics and Management in Honor of Lars Wahlbeck. Swedish School of Economics: Helsinki. Reprinted in Review of Economic Studies (1999) 66, 169-182.

Makkonen, T. (2000). "Kansanedustajien palkkaus EU-maissa, Norjassa ja Islannissa." [Pay of MPs in the member states of the European Union, in Norway and in Iceland] Eduskunnan kanslian julkaisu (Publication Series of the Finnish Parliament) 3/2000. In Finnish.

Matozzi, A. and Merlo, A. (2008) “Political Careers or Career Politicians?” Journal of Public Economics 92, 597-608.

Messner, M. and Polborn, M. K. (2004). “Paying Politicians.” Journal of Public Economics 88, 2423-2445.

Osborne, M. J. and Slivinski, A. (1996). "A Model of Political Competition with Citizen Candidates.” Quarterly Journal of Economics 111, 65-96.

Persson, T. and Tabellini, G. (2000). Political Economics.Cambridge, MA: MIT Press.

Poutvaara, P. and Takalo, T. (2007). “Candidate Quality.” International Tax and Public Finance 14, 7-27. 